\title{
Basic-to-acidic reversible pH switching with a merocyanine photoacid
}

\author{
Laura Wimberger ${ }^{\text {a }}$ Joakim Andréasson, ${ }^{b}$ and Jonathon E. Beves ${ }^{\text {a }}$
}

The application of merocyanine photoacids has been previously largely limited to neutral and acidic $\mathrm{pH}$ values. Here we introduce a new merocyanine photoacid with superior $\mathrm{pH}$ switching qualities. By increasing the $\mathrm{p} K_{\mathrm{a}}$ in the dark $\left(\mathrm{p} K_{\mathrm{a}}^{\text {dark }}\right)$ and the solubility we increased the reversible visible light induced $\mathrm{pH}$ jump to 3.5 units. Moreover, it is the first demonstration of a merocyanine photoacid able to generate a significant $\mathrm{pH}$ drop from a basic ( $\mathrm{pH} \mathrm{8.3)}$ to an acidic (pH 5.2) environment.

Every process occurring in an aqueous environment will be sensitive to $\mathrm{pH}$, whether it is enzyme functionality, controlling chemical reactivity, or the ocean's capacity to store carbon dioxide. By using light to induce proton dissociation, $\mathrm{pH}$ can be modified externally and non-invasively with high precision in space and time. Spiropyran/merocyanine photoswitches are reversible metastable photoacids that can significantly decrease the $\mathrm{pH}$ of an aqueous solution when irradiated with visible light, with subsequent recovery to the initial $\mathrm{pH}$ occurring thermally. The first reported merocyanine photoacid able to generate a substantial reversible $\mathrm{pH}$ jump of 1.5 units $\left(\mathrm{R}_{1}=\mathrm{H}, \mathrm{R}_{2}=\mathrm{H}, \mathrm{R}_{3}=\left(\mathrm{CH}_{2}\right)_{3} \mathrm{SO}_{3}{ }^{-} \text {, Fig. } 1\right)^{1}$ sparked interest in a wide-spread range of applications in supramolecular ${ }^{2}$ and materials chemistry. ${ }^{3}$ Recently developed merocyanines demonstrated increased $\mathrm{pH}$ jumps ranging from $2.5\left(\mathrm{R}_{1}=\mathrm{H}\right.$, $\mathrm{R}_{2}=\mathrm{H}, \quad \mathrm{R}_{3}=\left(\mathrm{CH}_{2}\right)_{4} \mathrm{SO}_{3}^{-} \quad 4$ and $\mathrm{R}_{1}=\mathrm{H}, \quad \mathrm{R}_{2}=$ polymer, $\left.\mathrm{R}_{3}=\left(\mathrm{CH}_{2}\right)_{3} \mathrm{SO}_{3}^{-}{ }^{5}\right)$ and $3.0 \mathrm{pH}$ units $\left(\mathrm{R}_{1}=\mathrm{MeO}, \mathrm{R}_{2}=\mathrm{H}\right.$, $\left.\mathrm{R}_{3}=\left(\mathrm{CH}_{2}\right)_{3} \mathrm{SO}_{3}^{-}\right)^{6}$ to the highest reported value of $3.2 \mathrm{pH}$ units $\left(\mathrm{R}_{1}=\mathrm{MeO}, \mathrm{R}_{2}=\mathrm{H}, \mathrm{R}_{3}=\left(\mathrm{CH}_{2}\right)_{3} \mathrm{NMe}_{3}{ }^{+}\right)^{7}$ The $\mathrm{pH}$ ranges these examples $^{4,6-7}$ can be used for is limited to near neutral or acidic environments. ${ }^{8}$ Herein we report a new merocyanine derivative 1 with a butyl sulfonate group $\left(R_{3}\right)$ and substituents $\mathrm{R}_{1}=\mathrm{MeO}$ and $\mathrm{R}_{2}=\mathrm{H}$ capable of generating an unsurpassed $\mathrm{pH}$ jump of 3.5 units. Moreover, it is the first demonstration of a $\mathrm{pH}$ jump covering a significant part of the basic region.

Merocyanine photoacid $\mathbf{1}$ was synthesized over three-steps (for full characterisation and data, see Supporting Information S2). The proton dissociation behaviour of 1 was studied in the dark and under visible light irradiation $(\lambda=455 \mathrm{~nm})$ by established methods. ${ }^{4}{ }^{7}$ In the dark the protonated merocyanine form $(\mathrm{MCH})$ is in equilibrium with the deprotonated merocyanine form $(\mathrm{MC})$ and the ring-closed spiropyran form (SP) (Figure 2ai). ${ }^{9}$ The $\mathrm{p} K_{\mathrm{a}}{ }^{\text {dark }}$ value was determined by measuring the UV-vis absorption spectra of equilibrated samples at $\mathrm{pH}$ 5.1-9.6 (Figure 2aii,iii see S4.3 in Supporting Information). This parameter accounts for the coupled equilibria between $\mathrm{MCH}, \mathrm{MC}$ and SP. The corresponding $\mathrm{p} K_{\mathrm{a}}$ value under irradiation, $\mathrm{p} K_{\mathrm{a}}{ }^{h v}$, is determined by the equilibrium between the metastable cis-MCH and SP form (Fig 2bi) $)^{4,7}$ and was calculated from the absorption spectra of equilibrated samples under visible light irradiation $(\lambda=455 \mathrm{~nm}$ ) over a $\mathrm{pH}$ range from 2.2 to 6.6 (Fig. 2 bii, iii).

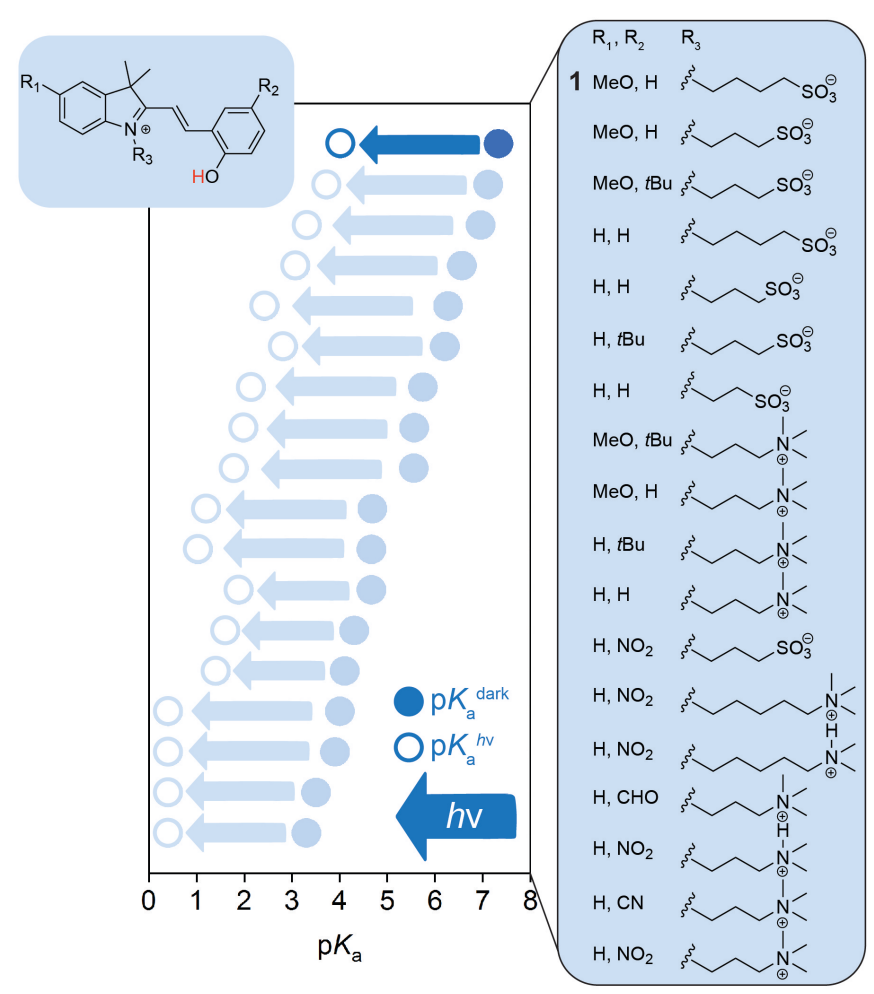

Fig. 1 Overview over $\mathrm{p} K_{\mathrm{a}}^{\text {dark }}$ and $\mathrm{p} K_{\mathrm{a}}{ }^{h v}$ values of reported ${ }^{4,6-7,10}$ merocyanine photoacids and derivative 1 with respective substitution patterns (right).

\footnotetext{
${ }^{a}$ School of Chemistry, UNSW Sydney, Sydney, New South Wales 2052, Australia. jbeves@unsw.edu.au

${ }^{b}$ Department of Chemistry and Chemical Engineering, Chalmers University of Technology, Göteborg 412 96, Sweden.
} 


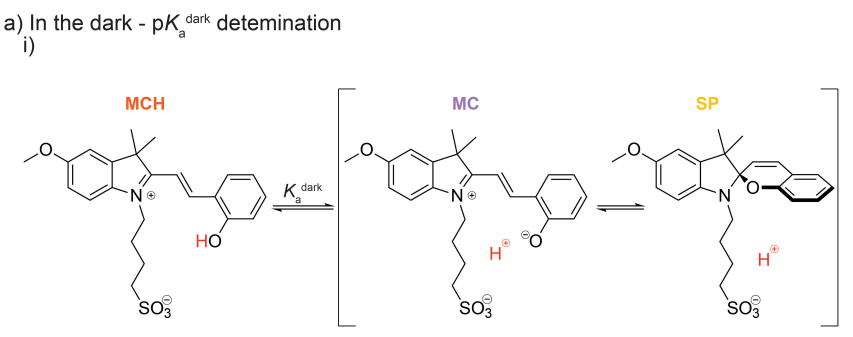

b) Under $h v(\lambda=455 \mathrm{~nm})-\mathrm{pK}_{\mathrm{a}}^{h v}$ detemination

i)
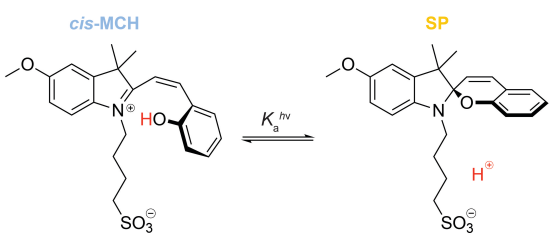
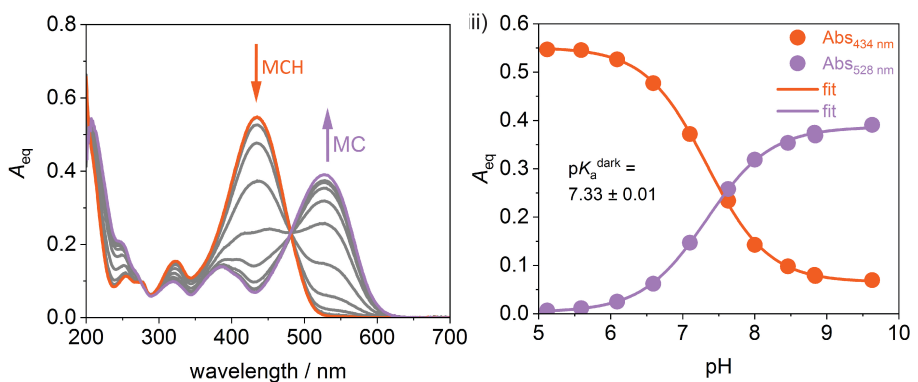

ii)

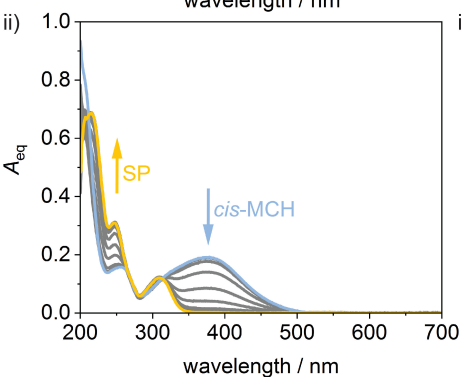

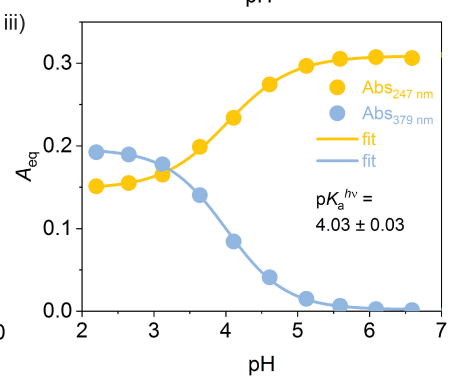

Fig. 2 Determination of $p K_{a}^{\text {dark }}$ and $p K_{a}{ }^{h v}$ by UV-vis absorption measurements of merocyanine photoacid 1. ai) Equilibrium in the dark between the protonated merocyanine form $(\mathrm{MCH})$ and the deprotonated form (MC) or respective ring closing product of $\mathrm{MC}$ - the spiropyran form (SP). aii) Absorption spectra of equilibrated samples in the dark at increasing $\mathrm{pH}$ values (orange: $\mathrm{pH}=5.1$, purple: $\mathrm{pH}=9.6$ ). aiii) Absorbance traces over the $\mathrm{pH}$ range of maxima characteristic for the $\mathrm{MCH}$ (orange, $\lambda=434 \mathrm{~nm}$ ) and $\mathrm{MC}$ forms (purple, $\lambda=528 \mathrm{~nm}$ ) with respective sigmoidal fit. Experimental conditions: [1] $=20.0 \mu \mathrm{M}$, [phosphate buffer] $=20 \mathrm{mM}, \mathrm{pH} 5.1-9.6, T=22{ }^{\circ} \mathrm{C}$. bi) Equilibrium under $455 \mathrm{~nm}$ light irradiation between the protonated metastable cis-merocyanine form (cis- $\mathrm{MCH}$ ) and the deprotonated ring closing product - the spiropyran form (SP). bii) Absorption spectra of equilibrated samples under $455 \mathrm{~nm}$ light irradiation at increasing $\mathrm{pH}$ values (blue: $\mathrm{pH}=2.2$, yellow: $\mathrm{pH}=8.8$ ). biii) Absorbance traces over the $\mathrm{pH}$ range of maxima characteristic for the cis-MCH (blue, $\lambda=379 \mathrm{~nm}$ ) and SP forms (yellow, $\lambda=247 \mathrm{~nm}$ ). Experimental conditions: $[1]=20.0 \mu \mathrm{M}$, [phosphate buffer] $=20 \mathrm{mM}, \mathrm{pH} 2.2-6.6, T=22{ }^{\circ} \mathrm{C}$

Both $\mathrm{p} K_{\mathrm{a}}^{\text {dark }}$ and $\mathrm{p} K_{\mathrm{a}}^{h v}$ are "pseudo" $\mathrm{p} K_{\mathrm{a}}$ values as they involve equilibria between other species than just the acid and the base, ${ }^{11}$ but are useful to describe the effective proton dissociation behaviour of merocyanine photoacids. The $\mathrm{p} K_{\mathrm{a}}^{\text {dark }}$ of 1 was determined as $7.33 \pm 0.01$ which is higher than reported values for related compounds (7.11 $\pm 0.03:^{7}$ $\mathrm{R}_{1}=\mathrm{MeO}, \mathrm{R}_{2}=t \mathrm{Bu}, \mathrm{R}_{3}=\left(\mathrm{CH}_{2}\right)_{3} \mathrm{SO}_{3}{ }^{-} ; 6.95 \pm 0.03:^{6} \mathrm{R}_{1}=\mathrm{MeO}$, $\left.\mathrm{R}_{2}=\mathrm{H}, \mathrm{R}_{3}=\left(\mathrm{CH}_{2}\right)_{3} \mathrm{SO}_{3}{ }^{-}\right)$. The proton dissociation behaviour of 1 under light irradiation was also shifted to higher $\mathrm{pH}\left(\mathrm{p} K_{\mathrm{a}}{ }^{h v}=\right.$ $4.03 \pm 0.03)$ compared to reported values of related compounds $\left(3.72 \pm 0.01:^{7} \mathrm{R}_{1}=\mathrm{MeO}, \mathrm{R}_{2}=t \mathrm{Bu}, \mathrm{R}_{3}=\left(\mathrm{CH}_{2}\right)_{3} \mathrm{SO}_{3}{ }^{-}\right.$; $\left.3.43 \pm 0.04:^{6,12} \mathrm{R}_{1}=\mathrm{MeO}, \mathrm{R}_{2}=\mathrm{H}, \mathrm{R}_{3}=\left(\mathrm{CH}_{2}\right)_{3} \mathrm{SO}_{3}^{-}\right)$. This also confirms the trend ${ }^{7}$ that the difference between $\mathrm{p} K_{\mathrm{a}}{ }^{\text {dark }}$ and $\mathrm{p} K_{\mathrm{a}}{ }^{h v}$, defined as the photoacidity parameter ${ }^{4}\left(\Pi=\mathrm{p} K_{\mathrm{a}}{ }^{\text {dark }}-\right.$ $\mathrm{p} K_{\mathrm{a}}{ }^{h v}$ ) is relatively constant across different merocyanine compounds. The photoacidity parameter of photoacid $\mathbf{1}$ is $3.29 \pm 0.03$ which is in the range of previous examples (derivatives in Fig.1 with $\mathrm{R}_{2}: \mathrm{H}$ or $t \mathrm{Bu}$ ) of $3.38 \pm 0.03$ to $3.85 \pm$ 0.08 . $^{4-7}$

Increasing the length of the side chain $\left(R_{3}\right)$ by just one methylene group led to increased solubility in line with previously reported compound $\left(\mathrm{R}_{1}=\mathrm{H}, \mathrm{R}_{2}=\mathrm{H}, \mathrm{R}_{3}=\left(\mathrm{CH}_{2}\right)_{4} \mathrm{SO}_{3}{ }^{-}\right.$ ). ${ }^{4}$ We were able to prepare $3 \mathrm{mM}$ solutions of merocyanine 1 which is around one order of magnitude higher than the solubility of propyl sulfonate analogue ${ }^{6}(c=0.4 \mathrm{mM}$ ). As expected, the increased solubility of 1 resulted in improved $\mathrm{pH}$ switching properties. A $3 \mathrm{mM}$ solution of 1 in $20 \mathrm{mM} \mathrm{KCl}$ was adjusted to $\mathrm{pH} 7.3$ by adding minimal amounts of aqueous potassium hydroxide solution (1.0 M). Exposure to visible light at $\lambda=450 \mathrm{~nm}$ resulted in a drop to $\mathrm{pH} 3.8$, equivalent to a 3.5 unit reversible $\mathrm{pH}$ jump (Fig. 3a). This switching process was repeated over 10 cycles with only minimal loss in the $\mathrm{pH}$ jump (98\% recovery/cycle, Fig. 3b). Adjusting the initial $\mathrm{pH}$ to 8.3 yielded a light-induced $\mathrm{pH}$ jump of 3.2 units to $\mathrm{pH} 5.2$ (Fig. $3 \mathrm{c}$ ). By comparison, the corresponding switching of a previously reported merocyanine $\left(\mathrm{R}_{1}=\mathrm{MeO}, \mathrm{R}_{2}=\mathrm{H}, \mathrm{R}_{3}=\left(\mathrm{CH}_{2}\right)_{3} \mathrm{NMe}_{3}{ }^{+}\right)$at an initial $\mathrm{pH}$ of 7.5 resulted in a pH drop of only 1.6 units whereas an initial pH of 8.8 gave a drop of just 0.1 units. ${ }^{7}$ Repeated cycling of the $\mathrm{pH}$ jump for compound $\mathbf{1}$ from basic $(\mathrm{pH} 8.3)$ to acidic ( $\mathrm{pH} 5.2$ ) over 10 cycles also showed good stability (99\% recovery/cycle, Fig 3 d). Slightly improved stability at higher $\mathrm{pH}$ values confirms the behaviour observed for hydrolytic degradation in previous studies. ${ }^{4,} 6$ The $\mathrm{pH}$ switching capacity for initial $\mathrm{pH}$ values in the range of $\mathrm{pH} 7.2$ to $\mathrm{pH} 8.3$ was similarly good with $\mathrm{pH}$ jumps of 2.6-3.5 units, demonstrating that the initial $\mathrm{pH}$ can be adjusted as needed for relevant applications (details see Supporting Information S5.1). The light induced $\mathrm{pH}$ jump decreases significantly beyond $\mathrm{pH} 8.3$ due to incomplete bleaching of the $\mathrm{MC}(\mathrm{H})$ form (isomerization to the SP form), as shown by in situ NMR irradiation experiments in neutral to basic environments (see Supporting Information S3.3). The $\mathrm{pH}$ jump was only minimally influenced by temperature changes of $25 \pm 3^{\circ} \mathrm{C}$ with an observed variation of $<0.1 \mathrm{pH}$ units (see Supporting Information S5.2).

For application purposes it is also important to know the timeframe of the $\mathrm{pH}$ response. A quick $\mathrm{pH}$ response is useful when an abrupt change in environment is required, whereas a slow response can be advantageous for processes requiring slower $\mathrm{pH}$ changes (i.e. to control kinetic processes like gel 


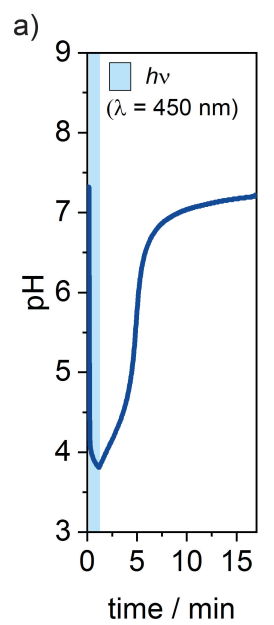

b)

c)
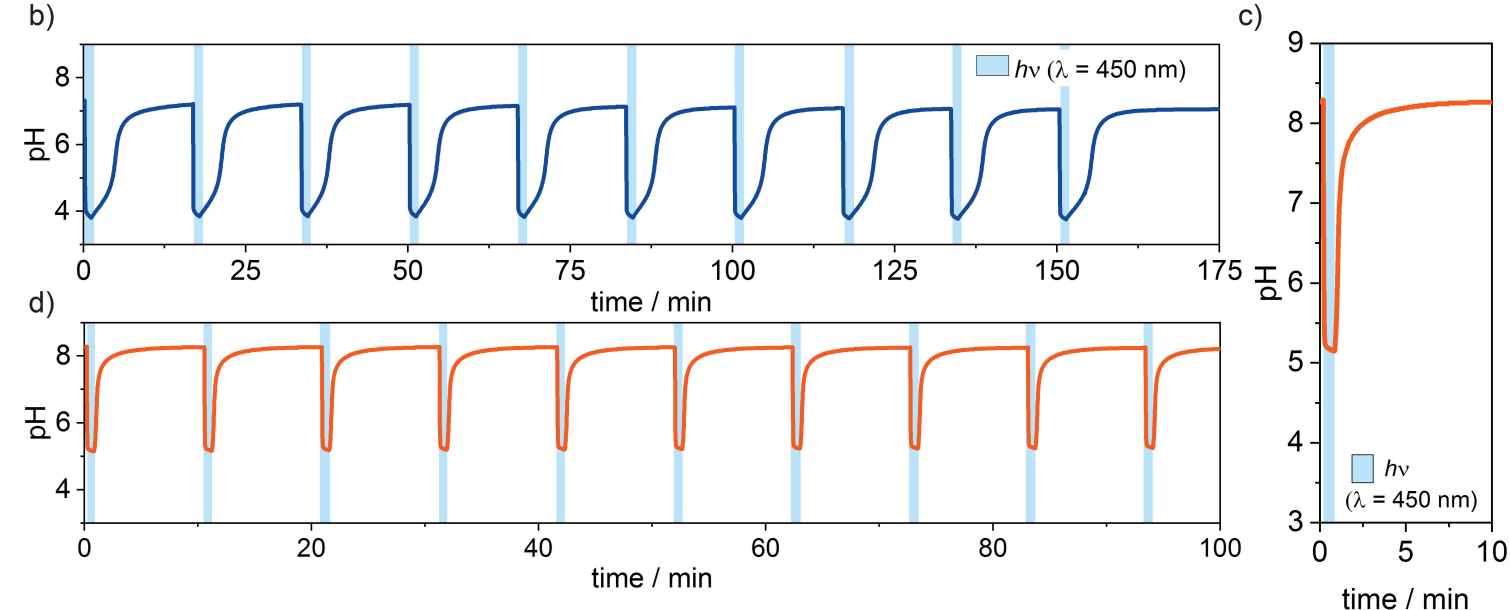

Fig. 3 Reversible visible light induced pH switching of a $3 \mathrm{mM}$ aqueous solution of merocyanine photoacid 1. a) pH jump from 7.3 to 3.8 units, b) pH switching from neutral to acidic repeated for 10 cycles, c) pH jump from 8.3 to 5.1 units, d) pH switching from basic to acidic repeated for 10 cycles.

formation). We show that merocyanine $\mathbf{1}$ could achieve $\mathrm{pH}$ drops within seconds $(<5 \mathrm{~s})$ under light irradiation whereas the thermal recovery occurred over minutes $(<20 \mathrm{~min})$. As expected, the thermal recovery is more sensitive to temperature than the photoisomerization. At $28^{\circ} \mathrm{C}$ the thermal recovery took approximately a third of the time than at $22{ }^{\circ} \mathrm{C}$ (7 $\mathrm{min}$ vs $\left.18 \mathrm{~min}\right)$.

In conclusion, we report a new merocyanine photoacid with improved solubility and the highest $\mathrm{p} K_{\mathrm{a}}^{\text {dark }}$ value with respect to reported examples. ${ }^{4,6-7,10}$ These improved properties enabled the highest visible-light-induced $\mathrm{pH}$ jump of 3.5 units (pH 7.3 to 3.8) with good stability over 10 cycles. Visible-lightinduced $\mathrm{pH}$ switching was extended well into the basic $\mathrm{pH}$ range for the first time with significant reversible $\mathrm{pH}$ drops from $\mathrm{pH} 8.3$ to 5.2 that could be repeated over 10 cycles with minimal loss in function. These switching cycles of considerable magnitude and access to $\mathrm{pH}$ switching from basic to acidic environments make merocyanine $\mathbf{1}$ a useful tool to control chemical and biological activity with visible light. Application of merocyanine $\mathbf{1}$ will significantly broaden the scope of $\mathrm{pH}$ sensitive systems that can now be externally (and non-invasively) controlled with visible light.

\section{Notes and references}

1. a) Z. Shi, P. Peng, D. Strohecker and Y. Liao, J. Am. Chem. Soc., 2011, 133, 14699-14703; b) Y. Liao, Acc. Chem. Res., 2017, 50, 1956-1964.

2. a) F. J. Rizzuto, C. M. Platnich, X. Luo, Y. Shen, M. D. Dore, C. Lachance-Brais, A. Guarne, G. Cosa and H. F. Sleiman, Nat. Chem., 2021, 13, 843-849; b) X. M. Chen, X. F. Hou, H. K. Bisoyi, W. J. Feng, Q. Cao, S. Huang, H. Yang, D. Chen and Q. Li, Nat. Commun., 2021, 12, 4993; c) J. Ryssy, A. K. Natarajan, J. Wang, A. J. Lehtonen, M. K. Nguyen, R. Klajn and A. Kuzyk, Angew. Chem. Int. Ed., 2021, 60, 5859-5863; d) N. Cissé and T. Kudernac, ChemSystemsChem, 2020, 2, e2000012; e) S. M. Jansze, G. Cecot and K. Severin, Chem. Sci., 2018, 9, 4253-4257; f) Q. Shi, Z. Meng, J. F. Xiang and C. F. Chen, Chem. Commun., 2018, 54, 3536-3539; g) J. Guo, H. Y. Zhang, Y. Zhou and Y. Liu, Chem. Commun., 2017, 53, 6089-6092; h) Y. Xu, J. Fei, G. Li, T. Yuan, Y. Li, C. Wang, X. Li and J. Li, Angew. Chem. Int. Ed., 2017, 56, 12903-12907; i) L. A. Tatum, J. T. Foy and I. Aprahamian, J. Am. Chem. Soc., 2014, 136, 17438-17441.

3. a) R. J. Li, C. Pezzato, C. Berton and K. Severin, Chem. Sci., 2021, 12, 4981-4984; b) V. X. Truong, J. Bachmann, A. N. Unterreiner, J. P. Blinco and C. Barner-Kowollik, Angew. Chem. Int. Ed., 2022, 10.1002/anie.202113076; c) S. Moreno, P. Sharan, J. Engelke, H. Gumz, S. Boye, U. Oertel, P. Wang, S. Banerjee, R. Klajn, B. Voit, A. Lederer and D. Appelhans, Small, 2020, 16, e2002135; d) X. Li, J. Fei, Y. Xu, D. Li, T. Yuan, G. Li, C. Wang and J. Li, Angew. Chem. Int. Ed., 2018, 57, 1903-1907; e) C. Maity, W. E. Hendriksen, J. H. van Esch and R. Eelkema, Angew. Chem. Int. Ed., 2015, 54, 998-1001; f) T. Zhang, L. Sheng, J. Liu, L. Ju, J. Li, Z. Du, W. Zhang, M. Li and S. X.-A. Zhang, Adv. Funct. Mater., 2018, 28, 1705532.

4. C. Berton, D. M. Busiello, S. Zamuner, E. Solari, R. Scopelliti, F. Fadaei-Tirani, K. Severin and C. Pezzato, Chem. Sci., 2020, 11, 8457-8468.

5. L. Yang, L. Caire da Silva, H. Thérien-Aubin, M. B. Bannwarth and K. Landfester, Macromol. Rapid Commun., 2019, 40, 1800713.

6. C. Berton, D. M. Busiello, S. Zamuner, R. Scopelliti, F. FadaeiTirani, K. Severin and C. Pezzato, Angew. Chem. Int. Ed., 2021, 60, 21737-21740.

7. L. Wimberger, S. K. K. Prasad, M. D. Peeks, J. Andreasson, T. W. Schmidt and J. E. Beves, J. Am. Chem. Soc., 2021, 143, 2075820768.

8. See Ref. 7: Reported merocyanine $\left(R_{1}=M e O, R_{2}=H, R_{3}=\right.$ $\left.\left(\mathrm{CH}_{2}\right)_{3} \mathrm{NMe}_{3}{ }^{+}\right)$achieved a pH drop of 1.6 units at an initial $\mathrm{pH}$ of 7.5 whereas an initial pH of 8.8 gave a drop of just 0.1 units.

9. a) R. Klajn, Chem. Soc. Rev., 2014, 43, 148-184; b) L. Kortekaas and W. R. Browne, Chem. Soc. Rev., 2019, 48, 3406-3424.

10. M. Hammarson, J. R. Nilsson, S. Li, T. Beke-Somfai and J. Andreasson, J. Phys. Chem. B, 2013, 117, 13561-13571.

11. Described in more detail in Ref. 4, 6-7.

12. with $425 \mathrm{~nm}$ excitation. When excited with $500 \mathrm{~nm}$ light the $\mathrm{p} K_{\mathrm{a}}{ }^{h v}$ was $3.31 \pm 0.04$ 


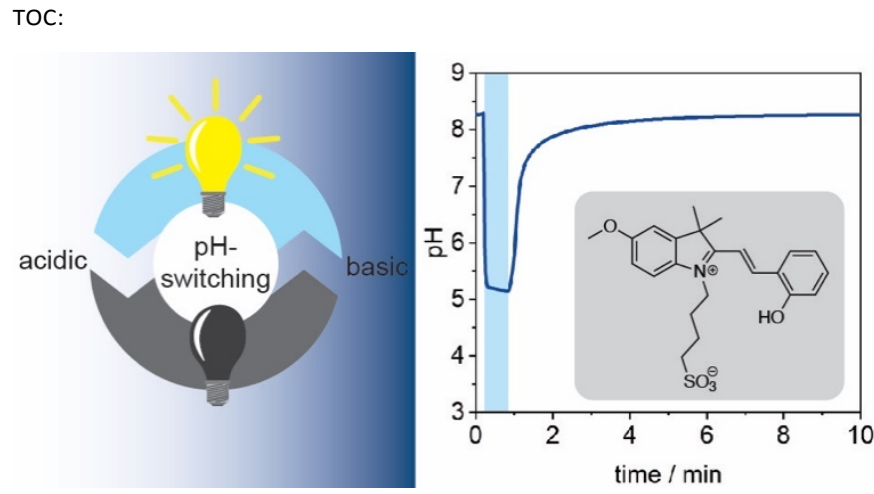

